\title{
The Seventh Art as a Soft Power Source for the United Arab Emirates
}

\author{
H. Enser and S.Koshy
}

\begin{abstract}
The United Arab Emirates is an entity quite unlike any other country. Joined together through will, family bonds, tolerance and unwavering loyalty to founding father Sheikh Zayed bin Sultan Al Nayhan's vision, the UAE is altering preconceptions by the West and the Far East about what a Middle Eastern country can achieve. Expatriates make up an overwhelming majority of the population but the pull to live, work and holiday in the UAE is not just down to sunshine. The presence of Hollywood stars, cinematic business minds and a need to bring the UAE to the top, are influencing decisions to convert subtly used soft power into a profitable and socio-economic cultural whirlwind of success. The UAE is a rising star in the realm of the seventh art and this paper explores the relationship.
\end{abstract}

Index Terms - Soft power, cinema, film industry, United Arab Emirates.

\section{INTRODUCTION TO SOFT POWER}

Henry Kissinger said: "we are entering a new era. Old international patterns are crumbling; old slogans are uninstructive [sic]; old solutions are unavailable," [1] in a 1975 conference addressing the United States' super power legacy, and whether or not the US would be able to continue with it. Perhaps at the time, when the Second World War was still in living memory and the Vietnam War was yet to end, this seemed dramatic, over-the-top scaremongering to a nation which, arguably through force and alongside their forceful allies were leaders in an arguably submissive or indifferent world.

Fast forward forty years, and the concepts of old - where rebellions were met with force is, as predicated by Kissinger, arguably not the leading or most popular way to get what any nation and any leaders crave - power. Instead, human rights have been brought to the forefront, and the: "ability to change the behaviour of states," [2] through manipulation and ideology is considered the optimum way to convince an individual, company or country that what someone or something else has is what they should strive for.

Termed co-optive or soft power, which will be used through this paper, Joesph. S. Nye Jr was a leading figure in realising and naming a phenomenon about: "intangible power resources such as culture, ideology, and institutions," [2] and recognising the actual power that these, in the hands of those possessing charismatic qualities, can wield.

In relation to the United Arab Emirates, Khatib argues that although: "the Middle East has been perceived globally as a place of conflict," the media, including cinematic ventures

H. Enser is a student of Media and Communication at the university of Wollongong in Dubai. (e-mail: hollyeolivia@gmail.com).

S. Koshy is Associate Professor, Arts and Humanities at the University of Wollongong in Dubai, Dubai, UAE. (e-mail: swapnakoshy@uowdubai.ac.ae). are giving the Middle East a: "central position," in their storytelling dynamics [3]. There are many reasons for this, and this paper will identify other key aspects later, but arguably the most prominent reasons for using the United Arab Emirates as a production and filming base, outside of Western countries, is safety, ease of access and the financial incentives the government offers.

\section{Soft Power, Cinema AND SAFETy IN THE UAE}

Wrongly or rightly depending on who is being asked, the Middle East has a reputation amongst its Western and Asian counterparts for conflict and for housing terror fundamentalists. Hollywood, as Viola Shafik explains in her book Arab Cinema: History and Cultural Identity: "equates fundamentalism with killing, kidnapping and torture," [4] and this has lead to film after film being created, in Hollywood at least, with Islam and Arabs portrayed as villains. Shaheen explains that before 9/11 there were around 1,100 films that portrayed Arabs in a negative way, and countless others after, such as The Kingdom (2007) and Traitor (2008) but he also exposes surprisingly: "exporting films to the Middle East may be bad diplomacy, but is good business [5]."With a large majority of the Middle Eastern population watching Hollywood blockbusters, this is something that arguably the leaders of United Arab Emirates, along with Queen Rania of Jordan have begun to subtly change through the use of soft power.

In 2014, the UAE's Foreign Minister Sheikh Abdullah bin Zayed Al Nahyan, whilst addressing the United Nations General Assembly in regard to global safety and terrorist groups in the region stated: "The acts of these terrorist organizations, which include indiscriminate killings, mass executions... are strongly condemned by the UAE [6]." Supporting this by agreeing with a united international stand against terrorism the United Arab Emirates challenged Western preconceptions that all Arabic nations are, in general, in support of terrorist groups. This preconception as Ridoauni explains: "whether the contact took place in the foregone centuries or it happens recently, the West preserve a persisting conceptualization of the Arabs and Muslims as an alien "Other" or rather "Enemy," [7] became arguably unsound.

In keeping with founding father Sheikh Zayed bin Sultan Al Nayhan's vision for the UAE which stressed on diplomacy, patience and justice [8] the United Arab Emirates has become a beacon of Islamic positivism. From alternative cultural and religious acceptance, to a high respect for women and openness to different ways of thinking - the Emirates has laid more than just the foundations to nurture international relations, which include the cinema industry.

However it is not just boldness in speaking out against terrorism and international injustices that is encouraging the dialogue between the West and the UAE. Arguably, it is the 
UAE's soft, power plays, that are even more crucial in the liaisons between Hollywood blockbusters, the stars that are in them and the region's film industry. The willingness to globalize and embrace diversity is an integral part of the UAE's international appeal as it: "connects the entire world," [9] and when linked to Friedman's somewhat controversial Golden Arches theory one could argue travelling, working and living in the UAE is, at least on surface-level, not all that different from a Western country. From high-street shops like New Look to international banks like HSBC you find: "globalization has brought down many of the walls that limited the movement and reach of people [10]." The English language is another example of the UAE's power play. It is the only language spoken on all continents and as described by Pennycook is: "one of the most powerful means of inclusion into or exclusion," [11] from positions, developments and relationships, and this includes cinematic ones. The UAE and its citizens have opened doors simply by being able to speak a secondary language, putting them at an advantage economically and socially. In Arab Media, Mellor et al look at the new chances globalization has brought to the United Arab Emirates and the undeniable links it has developed with both the West and the East [12]. The fast progression, the UAE has made, particularly Dubai which: "has rapidly transformed from a traditional fishing village into a booming modern 'westernized' city," [13] has made it a bigger, and better partner for any business deal.

Cinematically, Hollywood thrives on English language films, and by the UAE being able to genuinely promote themselves as open, English-speaking, culturally aware and accepting they have taken a huge, fast leap into an area incredibly new and incredibly promising.

\section{SOFt POWER AND EASE OF ACCESS AND FINANCIAL INCENTIVES IN ABU DHABI}

Whilst the United Arab Emirates as a whole is enticing to film makers, the stand out emirate in terms of ease of access and financial incentives, is the capital Abu Dhabi. From Bourne Legacy (2012) to Star Wars: The Force Awakens (2015) and Fast and Furious 7 (2015), as well as a slew of Bollywood films, Abu Dhabi has a unique and well thought through marketing strategy to ensure film makers consider shooting and do production there. Described by the Abu Dhabi Film Commission as an: "exciting, vibrant, multi-cultural city and a truly international capital," [14] the Abu Dhabi Film Commission (ADFC) extends a 30\% rebate to films or television that are either filmed partly or wholly in Abu Dhabi or which uses a local production company in the media zone twofour54. Although there are a few conditions that must be met before rebate can be given one of the most important is: "every project receiving the Rebate has an obligation to offer training and to provide internship opportunities [14].” By bringing in and offering a financial incentive for filmmakers, Abu Dhabi is attempting to secure its own film industry, with 'free' training for their own population. This is, as Townend and Gibbs describe why rebates can play a crucial role in: "essentially acting as a catalyst to jump-start markets and overcome initial barriers," [15] which would therefore change the local film market positiely. This combined with the region's policy of no sale tax showcases a thrifty model coupled with first-class services.

Aside from rebate, the ADFC also offers a number of attractive perks, which can potentially be a very important aspect to its appeal. Advertising it as a selection of: "full services offering for government servicing, permits, visa, script approval, and customs clearance and shooting permits," [14] the ADFC is attempting to make film-making easier. With professional help in all aspects of entering the country, and permits needed the ease of access that ADFC is supplying greatly takes the potential unease of filming in a foreign country off the table. This merged with its other perks such as an international crew being sourced for filmmakers if they do not want to spend money on their own crew being flown in and looked after whilst in Abu Dhabi, as well as the pull of filming in an enchanting place like Abu Dhabi have firmly placed the ADFC's goals on filmmakers' radars.

Knowing that something is not only easier to do but is also financially attractive is of key importance in an industry where films, particularly Hollywood blockbusters, are expected to make a staggering amount very quickly after release because of the sheer cost of making them. The ADFC's offer enables and entices filmmakers to an alternative to high-cost studios, large post-production costs and budget shooting on location.

\section{CURRENT HighS AND FutURE TRENDS}

Currently the United Arab Emirates has a unique selling point for visitors, and that is its celebrity endorsements, specifically those by movie stars. Film tourism is a viable business: "it has been widely recognised in tourism literature that destination image greatly influences tourist destination choice [16]." From Wallace Monument in Scotland seeing a $300 \%$ increase a year after the release of Braveheart (1995) to The Crown Hotel in Amersham, England which was featured in Four Weddings and A Funeral (1994) being fully booked for three years afterwards [16] there can be very little argument against film tourism.

Currently there is no statistical evidence from within the United Arab Emirates to verify whether filming locations have seen a rise. However, according to a Gulf News article which quotes Fernado Gibaja the general manager of the Jumeirah Zabeel Saray resort Mission Impossible: Ghost Protocol (2011), "greatly impacted Jumeriah Zabeel Saray's exposure to local and international markets ... the resort has also benefited from the many tourists who come and view the film location including memorabilia [17]."

The United Arab Emirates' businesses enroll celebrities to endorse their products as it is: "one of the most popular advertising techniques worldwide [18] ." For example Jennifer Aniston's USD \$5 million deal with Emirates airline, showcases the hope that brand owner's have in the power of film celebrities. Jennifer Aniston is massively recognisable and her pull, much in the same way as Nicole Kidman's Etihad endorsement ads help the companies by influencing those who would be considered their fans.

With this in mind, when looking to identify possible future trends, the United Arab Emirates has a couple of potential routes to follow. The first clearly is celebrity endorsement, which has been shown to pay off. Take for example Hillary Clinton's unsuccessful 2016 presidential election though she won the popular vote by a huge 2.5 million majority [19]. For most of her presidential candidate run, Clinton was inundated by support from celebrities - Beyonce and Jay- $Z$ even performed in her honour, Lena Dunham and Gwyneth Paltrow all supported the \#imwithher hashtag [20]. Celebrity endorsement in the long run may help the Emirates pull in 
more tourism, especially if those celebrities have featured in films or want to push directors to film in the region. This is a distinct and very real possibility which could lead to hundreds more films being produced in the UAE.

Secondly, when looking to identify possible future trends in terms of the United Arab Emirates cinematic soft power, the ultimate front-runner in charm offensive is China. Thussu explains that the Chinese centrally managed governmental strategies to get countries and states on its side [21], has so far paid off. Perhaps this is because: "for the Chinese, soft power means anything outside of the military and security realm, including not only popular culture and public diplomacy but also more coercive economic and diplomatic levers like aid and investments [22]." With similarities running through the United Arab Emirates and China, the ultimate survival and profile-raising way to succeed for the UAE is to watch and adapt as the Chinese run into problems. Shambaugh in his article China's Soft-Power Push: The Search for Respect explained that the Chinese realised their international image mattered, because of years of negative stereotypical Western and worldly press. With a barrage of money thrust into public relations offensives, President Xi Jinping aim is to build China into a: "socialist cultural superpower [23]." The United Arab Emirates, is already half-way there - with an extremely social-media savvy Royal Family and a keen sense of patriotism the United Arab Emirates has, already firmly placed itself on the map. From one-in-a-million seven star hotels to velvet supercars, the world's fastest roller coaster and plans to build bigger and better, the government is paving a path for a bright future. Gulf News' Francis Matthew describes the UAE's soft power as: "a significant example of how the country and Arab world is looking to support peaceful long-term alternatives [24]."

Whilst the United Arab Emirates is on such a high, and has constant plans for imaginative new creations, the future looks bright, especially with cinematic interest. As a place grows in popularity, both by celebrity endorsements and it's political international standing the United Arab Emirates' film industry can only grow with its popularity. A mix of soft power, globalisation and determination is the way forward for the United Arab Emirates and its cinema industry.

\section{A Future Problem?}

Of course, the use of soft power is not always plain sailing, especially for the United Arab Emirates. One such problem is the concept of 'Westernization' and whether or not this is impacting or derailing fundamental Islamic values and morals that the United Arab Emirates is supposed to be based on. Sandicki and Rice explain: "UAE citizens move through time and inadvertently borrow aspects of Westernized modern life at a rapid pace [25]," and this has caused a shift in traditional values. A constant argument that seems to pop up in international as well as in the local press, is whether or not the incorporation of Western elements to a culture has gone too far. With the country's roots based in Bedouin traditions, has the need for gadgets, fast cars and a party lifestyle impacted the UAE negatively, and what potentially does this mean? Still only a few decades old, the country needs more time to be able to answer the question of how the West and expats from the West are in the long-run going to influence and potentially change the Arabic way of life.

\section{CONCLUSION}

The United Arab Emirates is on a long cinematic journey to greatness. From marketing strategies such as rebate and celebrity endorsements to being considered a safe and tolerant haven in an otherwise conflicted Middle East, the United Arab Emirates has placed itself in a position of power. The use of soft power in this almost sudden elevation, over the last ten to twenty years cannot be denied. Through public relations exercises where statesmen argue for international fairness, breaking the long-time stereotype of the 'savage Arab' to something as simple as familiarity in using the same language - this Arab emirates of the United Arab Emirates is moving forward in the film industry at a fast rate.

Whether or not that rate is sustainable is a question that can only be answered through time, patience and hopefully more smart governmental decisions, but with China leading the so called charm offensive of soft power - the United Arab Emirates has a vantage point. From using and incorporating ideology from the Chinese's use of soft power to ultimately avoiding costly mistakes the Chinese have made in this unknown territory the United Arab Emirates has a predecessor to follow and to theoretically one-day take over from.

\section{REFERENCES}

[1] H. Kissinger (February 1975). A New National Partnership. THE DEPARTMENT OF STATE BULLETIN. [Online].LXXII (1860) p.197 Available: https://www.fordlibrarymuseum.gov/library/document/dosb/186 0. pdf\#page $=3$

[2] J. Nye (Autumn 1990). Foreign Policy. SOFT POWER [Online] 80 pp.153-177 Available http://faculty.maxwell.syr.edu/rdenever/PPA-730-27/Nye\%2019 90.pdf

[3] L. Khatib, Filming the Modern Middle East: Politics in the Cinemas of Hollywood and the Arab World, I.B.Tauris, 2006, p.1.

[4] V. Shafik, Arab Cinema: History and Cultural Identity, The American University in Cairo Press, 1998, p. 179.

[5] J. Shaheen, "Reel Bad Arabs: How Hollywood Vilifies People," THE ANNALS OF THE AMERICAN ACADEMY OF POLITICAL AND SOCIAL SCIENCE IN ISLA,” ENDURING MYTHS AND CHANGING REALITIES, vol. 588 pp. 171-193, July 2003.

[6] United Nations (September 2014). United Arab Emirates, at UN, urges Global Action [Online] Available: http://www.un.org/apps/news/story.asp?NewsID=48917

[7] D. Ridouani "The Representation of Arabs and Muslims in Wester Media," RUTA:REVISTA UNIVERSITARIA DE TREBALLS ACADEMICS, no.3, pp.1-15, 2011

[8] Crown Prince Court (2016) Sheikh Zayed bin Sultan Al Nayhan biography [Online] Available: https://www.cpc.gov.ae/en-us/TheUae/Pages/LateSheikhZayed. aspx

[9] N. U. Zaman UAE and Globalization: Attracting Foreign Investments, CRIN Verlag, 2011, p. 4

[10] T. Friedman The Lexus and The Olive Tree: Understanding Globalization, Picador, 1999, p. 14

[11] A. Pennycook, "English in the World," in Analyzing English in a Global Context: A Reader, A. Burns and C. Coffin, Routeledge, 2013, pp.78-89

[12] N. Mellor, M. Ayish, N. Dajani and K. Rinnawi, Arab Media, Cambridge UK \& Malden, 2011, pp.25-26

[13] M. Willemyns, The Rapid Transformation of Emirati Managers' Values in the United Arab Emirates, UOWD: UNIVERSITY OF WOLLONGONG IN DUBAI, 2008, p.2

[14] Abu Dhabi Film Commission (2016). Filming in Abu Dhabi, [Online] Available: http://www.film.gov.ae/en/filming-in-abu-dhabi/introduction 
[15] J. Townend and M. Gibbs (2000). The Role of Rebated in Market Transformation: Friend or Foe?, [Online] Available: http://www.eceee.org/library/conference_proceedings/ACEEE_ buildings/2000/Panel_6/p6_11/paper

[16] W. Rewtrakumphaiboon (June 2009) Film-induced Tourism: Inventing a Vacation to a Location [Online] Available: http://www.bu.ac.th/knowledgecenter/epaper/jan_june2009/pdf/ Walaiporn.pdf

[17] J. Tamimi (January 2015) Gulf News: Why the UAE is a Big Draw for Film-maker TV Producers, [Online] Available: http://gulfnews.com/business/economy/why-the-uae-is-a-big-dra w-for-film-makers-tv-producers-1.1437624

[18] L. Z. Leslie, Celebrity in the $21^{\text {st }}$ Century: A Reference Handbook, ABC-CLIO, 2011, p.45

[19] H. Agerholm (2, December 2016) The Independent: Hillary Clinton's lead over Donald Trump in popular votes passes 2.5 million [Online] Available: http://www.independent.co.uk/news/world/americas/us-election s/hillary-clinton-donald-trump-popular-vote-lead-25-million-a74 51661.html

[20] N. Robehmed (10, November 2016) Forbes: Celebrity Endorsements did not help Hillary Clinton win the Election [Online] Available: http://www.forbes.com/sites/natalierobehmed/2016/11/10/celebr ity-endorsements-did-not-help-hillary-clinton-win-the-election/\# 220910113e1e

[21] D.K. Thussu, Communicating India's Soft Power: Buddha to Bollywood, Palgrave McMillian series in Global Public Diplomacy, 2013, p.12

[22] [22] J. Kurlantzick, Charm Offensive: How China's Soft Power is Transforming the World, Yale University, 2007, p. 6

[23] D. Shambaugh (July/August 2015). China's Soft-Power Push The Search for Respect [Online] Available: https://www.foreignaffairs.com/articles/china/2015-06-16/chinas-soft-power-push

[24] F. Matthew (31, August 2016) UAE's Soft Power expands its Global Position [Online] Available http://gulfnews.com/opinion/thinkers/uae-s-soft-power-expandsits-global-position-1.1888643

[25] O. Sandicki and G. Rice, Handbook of Islamic Marketing, Edward Elgar Publishing, 2011, p.427 https://doi.org/10.4337/9780857936028
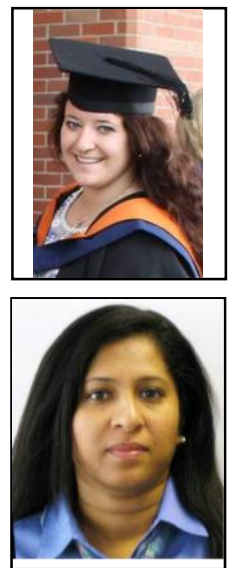

H.Enser is from the United Kingdom, and has a degree in Magazine Journalism from the University of Sunderland and is currently finishing off a Media and Communication Master Programme from the University of Wollongong in Dubai.

She has previously interned with NPI Media's digital platform myconcierge.com, and Immediate Media's Perfect Wedding magazine, whilst also undertaking work children's entertainment and hospitality.

Dr S.Koshy is a Media and Communications professor at the University of Wollongong in Dubai She is an award winning teacher and researcher, who is engaged in action-research on pedagogy with a focus on assessment methods. She has several media and marketing related publications and books to her credit. 